\title{
USING OF AGRICULTURAL DRAINAGE WATER FOR LETTUCE PRODUCTION IN HYDROPONIC SYSTEM
}

\author{
Zedan, A. M.*
}

ABSTRACT

The objectives of the present work were to study the effects of irrigation with Agricultural Drainage Water (ADW) on lettuce (Lactuca sativa L.) yield, quality, and water use efficiency (WUE) with hydroponic system. Five mixing treatments of Agricultural drainage water (ADW) with fresh water (mean normal irrigation water) were used T1:(100\% agricultural drainage water), T2:(75\% agricultural drainage water mixed with $25 \%$ fresh water), T3:(50\% agricultural drainage water mixed with 50\% fresh water), T4:(25\% agricultural drainage water mixed with $75 \%$ fresh water), and T5:( 100\% fresh water). Nutrient Film Technique (NFT) hydroponic system was developed with five pipes PVC and nutrient solution added in rates: $12.5 \%, 25 \%, 50 \%, 75 \%$, and $100 \%$ from standard nutrient solution for T1, T2, T3, T4, and T5, respectively. The results showed that lettuce plant can be produced in 50 days from planting to harvest by (NFT) hydroponic system. Moreover irrigation by using T3 had effectively increased the yields of green and dry matter. The higher Lettuce yields obtained with trend T3>T5>T2>T4>T1. And plants irrigated with T3 used water more efficiently than those irrigated with other water treatments. The higher water use efficiency (WUE) 39.96 $\mathrm{kg} / \mathrm{m}^{3}$ was obtained with T3 and the lower value 16.67 with T1. On the other hand mineral nutrient contents in dry matter of $N, P, K$, and $C a$ contents were obviously higher in plants irrigated with T5 than with other water treatments. Heavy metals $(\mathrm{Cd}, \mathrm{Ni}, \mathrm{Cr}$ and $\mathrm{Pb}$ ) contents in Lettuce shoots were higher in plants irrigated with T3 than those irrigated with other water treatments, but their levels did not reached the maximum allowed levels by FAO for edible crops.

Keywords: Agricultural Drainage Water, Hydroponic system, Lettuce, Water use efficiency.

*Lecturer of Agric. Eng., Agric. Eng. Dep., Fac. of Agric., Zagazig Univ., Egypt. 


\section{INTRODUCTION}

$\mathrm{N}$ ow it is very important to use alternative water resources such as agricultural drainage water to produce crops. Growing lettuce hydroponically is now becoming popular in drought prone areas to produce lettuce plants in large quantities with less water use. Egypt is an arid country, which covers an area of about $1,001,450 \mathrm{~km}^{2}$ of which only $4 \%$ is occupied by its population. The population has tripled during the last 50 years from 19 million in 1947 to about 83.5 million in 2012 and expected to be about 100 million by the year 2025 (Abdel-Lateef et. al., 2011). About $99 \%$ of the Egyptian population is concentrated within 5.5\% of the area of the Nile Valley and Delta region. They are extremely dependent on the River Nile for agriculture, drinking water and energy. Where, the actual water resources currently available for use in Egypt are $55.5 \mathrm{Bm}^{3} / \mathrm{yr}$ from river Nile, and $1.3 \mathrm{Bm}^{3} / \mathrm{yr}$ effective rainfalls on the northern strip of the Delta, non-renewable groundwater for western desert and Sinai, while water requirements for different sectors are in the order of $79.5 \mathrm{Bm}^{3} / \mathrm{yr}$. The gap between the needs and availability of water is about $20 \mathrm{Bm}^{3} / \mathrm{yr}$. This gap is overcome by recycling. Moreover, hydroponics (soilless) culture could lead to solve the global issues such as the shortage of water, environmental pollution, and instability of ecological system in various ways. Constituting high values for agricultural crops by using low water inputs and high fertilizer efficiencies is one of the methods used in addressing the environmental and resource problems (Sezen et. al., 2010).

On the other hand the agricultural sector is utilizing about $86 \%$ of the available water supplies; however, this amount of water that returns to drains from irrigated lands is relatively high (about 25 to 30\%). Generally, the drainage water from agriculture is collected, by an extensive drainage network. Currently about $5.5 \mathrm{Bm}^{3}$ of drainage water are being reused after mixing with fresh water. This amount is expected to increase up to $9.6 \mathrm{Bm}^{3}$ by the year 2017. In general, the utilization of agricultural drainage water (ADW) and marginal quality surface water is an emerging necessity to deal with severe water shortage in arid and semi-arid land. Upgrading of ADW may enable appropriate schemes for controlled application depending on treated ADW or via mixing with other sources of surface water. Its reuse in Egypt for agriculture could 
bridge the gap between the expected $\left(74\right.$ milliard $\left.\mathrm{m}^{3}\right)$ and required ( 85 milliard $\mathrm{m}^{3}$ ) water demand. In addition, Agriculture drainage water can be considered as a nutrient-rich resource that can be used for food production and thus help alleviate food shortages with minimum use of chemical fertilizers. However, whatever its application, and whatever the type and level of treatment technologies, they must meet the recommended microbiological and chemical quality guidelines. These presume low cost and minimal operational and maintenance requirements. Hydroponics is a method of growing plants in a soil-less media. The nutrient source is provided directly to the plant roots in solution. Recent studies have indicated that nutrients from treated ADW could be purified by using some plant species in a hydroponic system (Vaillant et al., 2004; Yang et al., 2008; Snow and Ghaly, 2008; Rababah and Ashbolt,2000; Rababah and al-Shuha, 2009). Hydroponic culture could be arranged with optimum environmental medium for crop growth in order to gain maximum yield and high quality products. However, there are few studies on the nutrient availability in Agriculture drainage water for optimum plant growth, pathogen contamination in edible parts of the plant and nutritional quality of vegetables grown in Agriculture drainage water using the hydroponics system. One of the most important aspects of fresh food is its nutritional quality; however, it is not clear whether Agriculture drainage water is able to provide necessary nutrients to food crops as well as adequate nutritional quality of the produce. Brandley and Marulanda (2000) reported that hydroponic vegetables production technique requires only about $10-20 \%$ of the water needed to produce the same amount of crop in soil culture. While Al-Karaki (2010) reported that only $3-5 \%$ of water is needed to produce the same amount of plants in comparison to that produced under field conditions. Gonnella M., et al., (2003) found that Water consumption was near to $80 \mathrm{~L} / \mathrm{m}^{2}$ when lettuce grown in floating system regardless of plant density, while WUE resulted on average $3.5 \mathrm{~g}$ of leaf dry matter produced per liter of water consumed. The benefits of hydroponic agriculture are numerous. In addition to higher yields and water efficiency, when practiced in a controlled environment, hydroponic systems can be designed to support continuous production throughout the year (Brechner and Both, 2014). Hydroponic 
systems are very versatile and can range from rudimentary backyard setups to highly sophisticated commercial enterprises. Various commercial and specialty crops can be grown using hydroponics including tomatoes, cucumbers, peppers, eggplants, strawberries, and many more. Leafy vegetables, such as lettuce can also be grown hydroponically and perform best using the nutrient film technique (NFT) (Tognoni and Pardossi, 2015). Hydroponic NFT production involves the circulation of a nutrient solution through shallow channels in a closedloop system (Albright and Langhans,2014). Hydroponic systems are optimal efficiency in the use of water and nutrients, with high environmental benefit (Vernieri et al., 2005). The current study aimed to investigate Lettuce yield, water use efficiency, and quality and heavy metal contents of the hydroponically produced Lettuce using agricultural drainage water $(\mathrm{ADW})$ for irrigation and compare it with fresh water irrigation.

\section{MATERIALS AND METHODS}

The experimental work was carried out during 2013 at the Department of Soil and Water Research, Nuclear Research Center, Atomic Energy Authority, Inshas, Egypt. It's located at $30^{\circ} 24^{`} \mathrm{~N}$ latitude, $31^{\circ} 35^{`} \mathrm{E}$ longitude while the altitude is $20 \mathrm{~m}$ above the sea level. The Nutrient Film Technique (NFT) culture was developed and manufactured at a local workshop used in this work.

Lettuce (Lactuca sativa L.) seeds were sowing on 1 September. 2013 in Rockwool and transplanted 3 week later into rock wool blocks. On 21 September 2013, at the four- to five-leaf stage, transplants were placed in net cups and were inserted in the NFT hydroponic systems. The NFT systems were made of plastic PVC Pipes $(300 \mathrm{~cm}$ long $\times 4$ inch $(10.16$ $\mathrm{cm}$ ) diameter) set on a flat surface with a $0.1 \%$ slope. Each experimental bloc had twelve plants; each effluent was complemented with appropriated nutrient solution. Block with five treatments and three repetitions of each treatment were applied showed in Figure 1. After seeding, lettuces were transferred to the experimental units. Irrigation was added by a little submersible pump (Mp-1500, power 40W, 50-60 Hz) was used to pump from the circulating tank to the head of the NFT channels where the plants were grown bare-rooted. The irrigation of plants was programmed with a 
timer to put on the pumps 4 times every day for 5 minutes per time and nutrient solution was delivered at $2 \mathrm{~L} \cdot \mathrm{min}^{-1}$. Nutrient solutions were monitored and adjusted daily for $\mathrm{pH}$ and electrical conductivity (EC). In the NFT system the solution was recycled not replaced but adjusted based on $\mathrm{pH}$ and $\mathrm{EC}$ measurements.

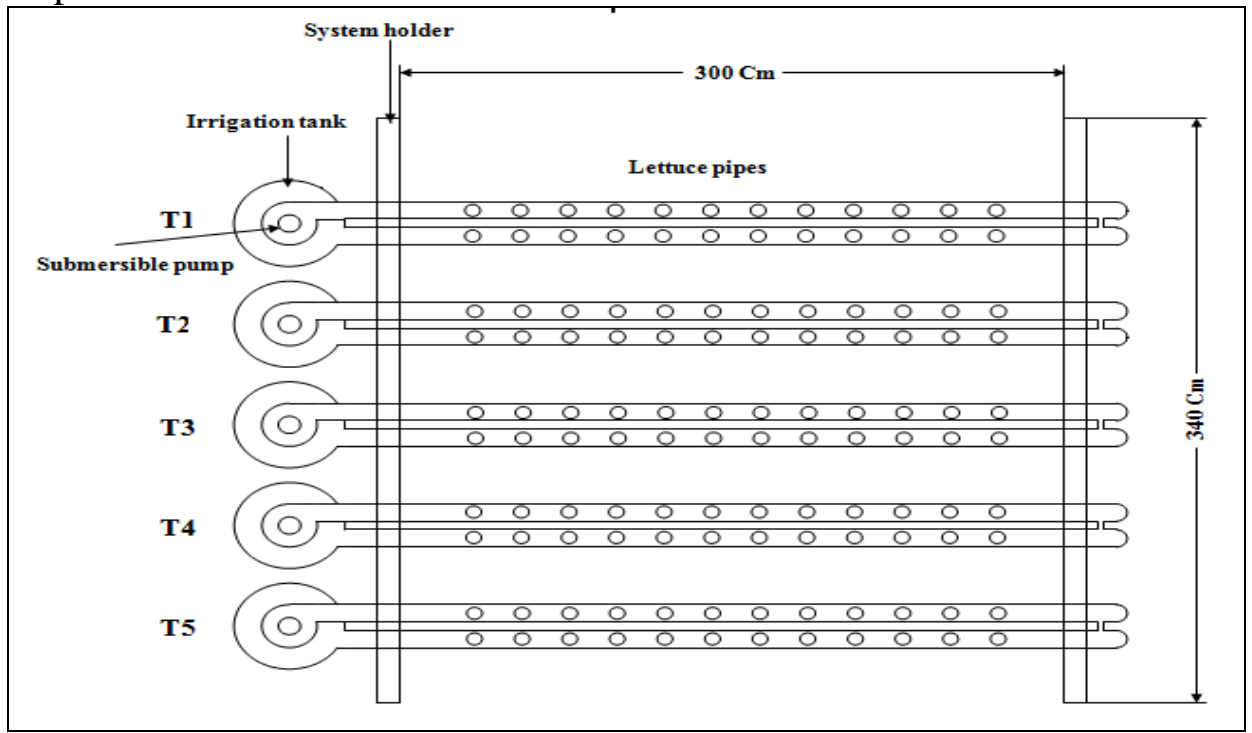

Figure 1: Schematic layout of the hydroponic system used in the study

The seeds were obtained from Agricultural Research Centre, Dokki, Cairo, Egypt. Lettuce (Lactuca sativa L.) seeds were subjected to a germination test to check for their viability before being used; the results showed that the germination percentage was $97 \%$. Seeds of lettuce were cleaned from debris and other foreign materials. Then the cleaned seeds were surface sterilized by soaking for 30 minutes in a $20 \%$ sodium hypochlorite solution (Clorox bleach) to prevent the formation of mould. Planting tubes and the growing net cups also were cleaned and disinfected. The seeds were washed well from residues of bleach and re-soaked in tap water overnight (about 12 hours) before sowing. Seeds were sown in the polystyrene trays lined with black plastic sheets and have holes at the bottom to allow drainage of excess water from irrigation.

\section{Irrigation treatments}

Pipes were irrigated by programming a timer to put on the pumps four times every day for five minutes per time with five water treatments: Five 
concentrations of Agricultural drainage water (ADW) were used T1: (100\% agricultural drainage water), T2: (75\% agricultural drainage water mixed with $25 \%$ fresh water (normal irrigation water), T3: ( $50 \%$ agricultural drainage water mixed with $50 \%$ fresh water), T4: ( $25 \%$ agricultural drainage water mixed with $75 \%$ fresh water), and T5: ( $100 \%$ fresh water). The Agricultural drainage water (ADW) was obtained from the outlet of drainage system of Minayer Region with a capacity of 2,500 $\mathrm{m}^{3} /$ day. Adequate nutrient solutions was added in each treatment with rates of $12.5 \%, 25 \%, 50 \%, 75 \%$, and $100 \%$ from standard nutrient solution for T1, T2, T3, T4, and T5 respectively to enhance plant growth and its contents of the nutritional elements. The irrigation system was installed in hydroponics system as follows: the different concentration of mixed agricultural drainage water was pumped from a 50L reservoir to the channel where plants were grown. The 4 inch diameter x $3 \mathrm{~m}$ length channels were connected by an inlet and outlet to the reservoir. The volume of solution in one channel at any one time was approximately 5L. The effluent was drained by gravity flow back into the reservoir.

\section{Water use efficiency}

Planting pipes were irrigated four times every day for five minutes from each water type to provide enough water to keep the seedlings moist. Daily amounts of water used in irrigation were recorded to compute the total amounts used in irrigation throughout the experiment. Drained water was recycled in the plastic tanks which were placed under each planting pipe. The total water used by plants (liters/pipe) was computed as the following:

Water consumption $\left(\mathrm{m}^{3} / \mathrm{m}^{2}\right)=$ Total irrigation water in tank at the beginning of the experiment - Total irrigation water in tank at the end of the experiment.

Water use efficiency (WUE) was determined according to Awady et al. (1976) and Bos (1980) using the following equation:

$$
W U E=\frac{\text { Average yield } \mathrm{kg} / \mathrm{fed}}{\text { Amount of applied water } \mathrm{m}^{3} / \mathrm{fed}} \mathrm{kg} / \mathrm{m}^{3}
$$

$\mathrm{WUE}=\mathrm{kg}$ fresh lettuce produced $/ \mathrm{m}^{3}$ water used. 


\section{Lettuce yield}

At the end of experiment (50 days after seeding), the produced fresh lettuce was harvested and green plants with their root mats in the tubes were harvested and the following data were recorded: total fresh and dry lettuce yields, plant height, and leaves number.

\section{Chemical analysis}

Mineral nutrient analyses

Representative fresh green lettuce samples $(150 \mathrm{~g})$ from each treatment were taken in four replicates at harvest, oven-dried at $70^{\circ} \mathrm{C}$ for 48 hours, ground to pass a $0.5 \mathrm{~mm}$ sieve, and digested used $\mathrm{H}_{2} \mathrm{SO}_{4}$ and $\mathrm{H}_{2} \mathrm{O}_{2}$ and then used for chemical analysis. The nitrogen content was determined using Kjeldahl's method. Samples for the determination of mineral nutrients were prepared using dry ashing method (Schouwenberg and Walinge, 1973). Phosphorus was determined using spectrophotometer (Watanabe and Olsen 1965); potassium and sodium by flame photometer (Ryan et al., 2001), $\mathrm{Ca}, \mathrm{Mg}, \mathrm{Mn}, \mathrm{Zn}$ and B by Atomic Absorption Spectrometer (Buck type 210). Some nutritional elements (N, P, K, Ca, Mg, Zn, Na, and B) for various irrigation waters were also analyzed.

\section{Heavy metals analysis}

Heavy metals analyses were carried out at the Department of Soil and Water Research, Nuclear Research Center, Atomic Energy Authority, Inshas, Egypt. Dried and ground plant samples were analyzed for heavy metals $\mathrm{Cd}, \mathrm{Ni}, \mathrm{Cr}$, and $\mathrm{Pb}$ were measured in the 0.2 portion dry ash digestion for the lettuce dried samples. Chemical analyses for various irrigation waters were also carried out separately for heavy metals $(\mathrm{Cd}, \mathrm{Ni}$, $\mathrm{Cr}$ and $\mathrm{Pb}$ ).

\section{RESULTS AND DISCUSSION}

Irrigation water quality

The analysis of irrigation water used for the various treatments was showed in Table 1 . The salinity of water was $0.89 \mathrm{dS} / \mathrm{m}$ for fresh water and $2.63 \mathrm{dS} / \mathrm{m}$ for Agricultural drainage water (ADW). The $\mathrm{pH}$ values were 7.42 for the fresh water and 7.95 for the ADW. Nitrogen, K, Na, $\mathrm{Cl}$ and $\mathrm{Zn}$ were present in higher concentrations in ADW compared to fresh water (Table 1). However, similar amounts of $\mathrm{P}, \mathrm{Mg}$, and $\mathrm{B}$ were 
recorded in both ADW and fresh water. The concentrations of these elements are considered lower than those recommended for nutrient solutions in crop production (e.g., vegetables) under hydroponic systems according to Benton (2005).

To know the potential risk of heavy metals in irrigation water to plants and hence human beings, it is necessary to evaluate their concentrations in ADW. The heavy metals concentrations of ADW and fresh water used in this study was presented in Table 2. Although the chromium, cadmium, nickel, and lead contents in ADW are much higher than those in fresh water, the levels of these elements in ADW are lower than the acceptable levels set for irrigation water for crop production according to FAO guidelines (FAO, 1992).

Table 1. The characteristics of fresh water and ADW used for irrigation in this study

\begin{tabular}{|c|c|c|}
\hline Parameter & $\begin{array}{c}\text { Fresh water } \\
\text { (Normal irrigation water })\end{array}$ & $\begin{array}{c}\text { Agricultural drainage water } \\
(\text { ADW })\end{array}$ \\
\hline $\mathrm{EC} \mathrm{dS} / \mathrm{m}$ & 0.89 & 2.63 \\
\hline $\mathrm{pH}$ & 7. 42 & 7.95 \\
\hline $\mathrm{DO}(\mathrm{mg} / \mathrm{l})$ & - & 2.8 \\
\hline BOD5 (mg/l) & - & 40 \\
\hline $\mathrm{COD}(\mathrm{mg} / \mathrm{l})$ & - & 38 \\
\hline $\mathrm{NO}_{3}-\mathrm{N}(\mathrm{mg} / \mathrm{l})$ & 14 & 23 \\
\hline $\mathrm{Cl}(\mathrm{mg} / \mathrm{l})$ & 17 & 129 \\
\hline $\mathrm{PO}_{4}-\mathrm{P}(\mathrm{mg} / \mathrm{l})$ & 4.96 & 6.58 \\
\hline $\mathrm{Ca}(\mathrm{mg} / \mathrm{l})$ & 48.12 & 59.32 \\
\hline $\operatorname{Mg}(\mathrm{mg} / \mathrm{l})$ & 15.9 & 17.3 \\
\hline $\mathrm{K}(\mathrm{mg} / \mathrm{l})$ & 98 & 118 \\
\hline $\mathrm{Na}(\mathrm{mg} / \mathrm{l})$ & 78.4 & 389 \\
\hline $\mathrm{Zn}(\mathrm{mg} / \mathrm{l})$ & 0.016 & 0.15 \\
\hline $\mathrm{B}(\mathrm{mg} / \mathrm{l})$ & 0.038 & 0.050 \\
\hline
\end{tabular}


Table 2. Toxic elements content (mg. $\left.\mathrm{L}^{-1}\right)$ in water used for irrigation and the maximum concentrations of heavy metals in ADW allowed to be used for irrigation according to FAO (1992).

\begin{tabular}{|c|l|c|c|}
\hline Heavy Metal & ADW & $\begin{array}{c}\text { Fresh water } \\
\text { (Normal irrigation water })\end{array}$ & Maximum concentrations \\
\hline Chromium $(\mathrm{Cr})$ & 0.0070 & 0.0018 & 0.10 \\
\hline Cadmium $(\mathrm{Cd})$ & 0.0023 & 0.0004 & 0.01 \\
\hline Nickel $(\mathrm{Ni})$ & 0.0082 & 0.0004 & 0.20 \\
\hline Lead $(\mathrm{Pb})$ & 0.167 & 0.0029 & 5.00 \\
\hline
\end{tabular}

\section{Lettuce yield}

Lettuce fresh weight (shoots and roots) as affected by different water quality was presented in Table (3), and graphically illustrated by Fig. (2). It is obvious that treatment of $50 \%$ drainage water mixed with $50 \%$ fresh water (T3) induced the highest value of shoots and roots fresh weight followed by treatment (T5), then the treatment (T2). On the other hand, the treatment of $100 \%$ drainage water (T1) resulted in the lowest value of shoots and roots fresh weight followed by T4.

The results presented in Table 3 showed that higher yields of fresh and dry matter were recorded in plants irrigated with T3 more than for others. Table 3 and Figures 2, 3 showed that lettuce yields (on fresh green and dry weight basis), plant heights and leaves number at harvest. Average fresh Lettuce yield obtained were 4.00, 7.42, 9.99, 7.25, and $7.77 \mathrm{~kg} / \mathrm{m}^{2}$ under irrigation with $\mathrm{T} 1, \mathrm{~T} 2, \mathrm{~T} 3, \mathrm{~T} 4$, and $\mathrm{T} 5$, respectively. It could be concluded that, the application of irrigation with $\mathrm{T} 3$ resulted in high increase in fresh green yield production of lettuce plant, in addition the yield production under application of different water treatment could be ranked in the following descending order: T3>T5>T2>T4>T1. Similar trends were observed with dry yield, where Average dry Lettuce yield obtained were $0.20,0.37,0.49,0.36$, and $0.39 \mathrm{~kg} / \mathrm{m}^{2}$ under irrigation with $\mathrm{T} 1, \mathrm{~T} 2, \mathrm{~T} 3, \mathrm{~T} 4$ and $\mathrm{T} 5$, respectively. Where the high dry yield production was obtained with T3 followed by T5, T2 and T4, then the lowest dry yield production was obtained with T1 similar results found by Gonnella M. et al., (2003) and Keller R. et al., (2005). These results also agreed with those obtained by Khater (2006) and Genuncio et al., (2012) who's found that the 
highest values of fresh and dry mass were found with a flow rate of 1.5 $\mathrm{Lh}^{-1}$ plant ${ }^{-1}$. Plant dry matter was reduced with increasing salinity and this is consistent with Al-Maskri A. et al.,( 2010 ). Regarding to plant height, Average Lettuce height obtained were 44.34, 58.58, 62.16, 58.33 and $60.75 \mathrm{~cm}$ under irrigation with T1, T2, T3, T4 and T5, respectively. the highest plant were obtained with T3 that's may be due to salinity level provide more nutrients availability when compared with other treatments this results agreement with Al-Maskri A. et al., ( 2010).

Table3. Lettuce (fresh, dry) yield, plant height, and leaves numbers of lettuce plant produced under (NFT) hydroponic conditions and irrigated with different concentrations of Agricultural Drainage Water (ADW).

\begin{tabular}{|c|c|c|c|c|}
\hline Water treatments & $\begin{array}{c}\text { Fresh } \\
\text { yield } \\
\mathrm{kg} / \mathrm{m}^{2}\end{array}$ & $\begin{array}{c}\text { Dry yield } \\
\mathrm{kg} / \mathrm{m}^{2}\end{array}$ & $\begin{array}{c}\text { plant height, } \\
\mathrm{cm}\end{array}$ & $\begin{array}{c}\text { leaves } \\
\text { number }\end{array}$ \\
\hline $\mathrm{T} 1$ & 4.00 & 0.20 & 44.32 & 17 \\
\hline $\mathrm{T} 2$ & 7.42 & 0.37 & 58.58 & 20 \\
\hline $\mathrm{T} 3$ & 9.99 & 0.49 & 62.16 & 25 \\
\hline $\mathrm{T} 4$ & 7.25 & 0.36 & 58.33 & 27 \\
\hline $\mathrm{T} 5$ & 7.77 & 0.39 & 60.75 & 30 \\
\hline
\end{tabular}

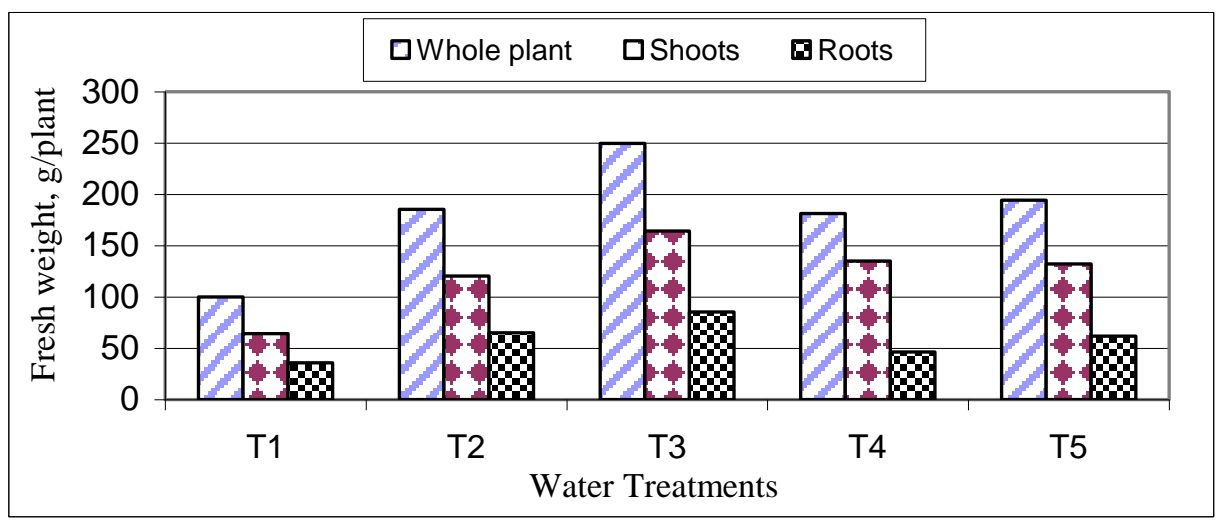

Figure 2: Effect of irrigation water treatments on fresh weight (g.plant ${ }^{-1}$ ) of Lettuce plant. 


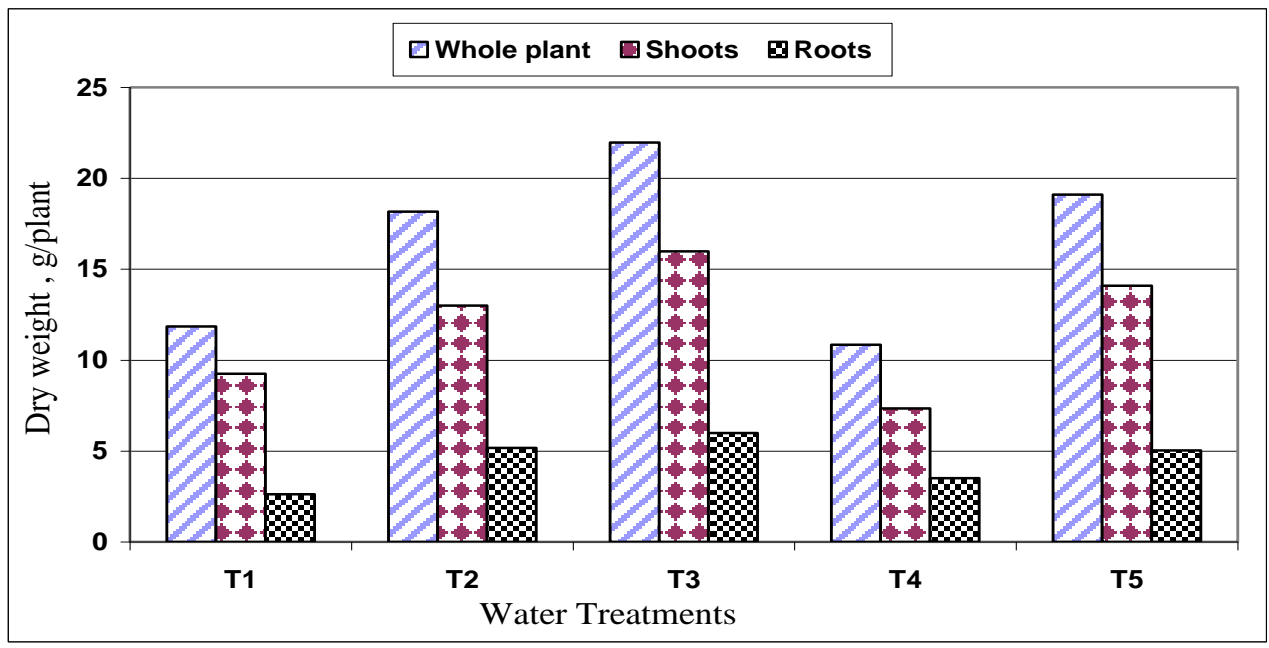

Figure 3: Effect of irrigation water treatments on dry weight (g.plant $\left.{ }^{-1}\right)$ of Lettuce plant

\section{Lettuce plant height}

Lettuce plant height (shoots and roots) as affected by different water quality is presented in Table (3), and graphically illustrated by Fig. (4). It is obvious that treatment T4 induced the highest value of shoot height followed by treatment (T3), then the treatment (T5). On the other hand, the treatment of $100 \%$ drainage water (T1) resulted in the lowest value of shoot height followed by $\mathrm{T} 2$. On the base of fully drainage water treatment, other water quality treatments reflected relative increase in shoot height by about $3 \%, 29 \%, 50 \%$ and $18 \%$ over T1 for T2, T3, T4 and $\mathrm{T} 5$, respectively.

On the other hand, results of root height showed that treatment of $75 \%$ drainage water mixed with $25 \%$ fresh water (T2) induced the highest value of root height followed by (T5), then the treatment (T3). On the other hand, the treatment (T1) resulted in the lowest value of root height followed by $\mathrm{T} 4$.

In general, the highest plant were obtained with T3 that's may be due to salinity level provide more nutrients availability when compared with other treatments this results agreement with Al-Maskri, A., et al. ( 2010). 


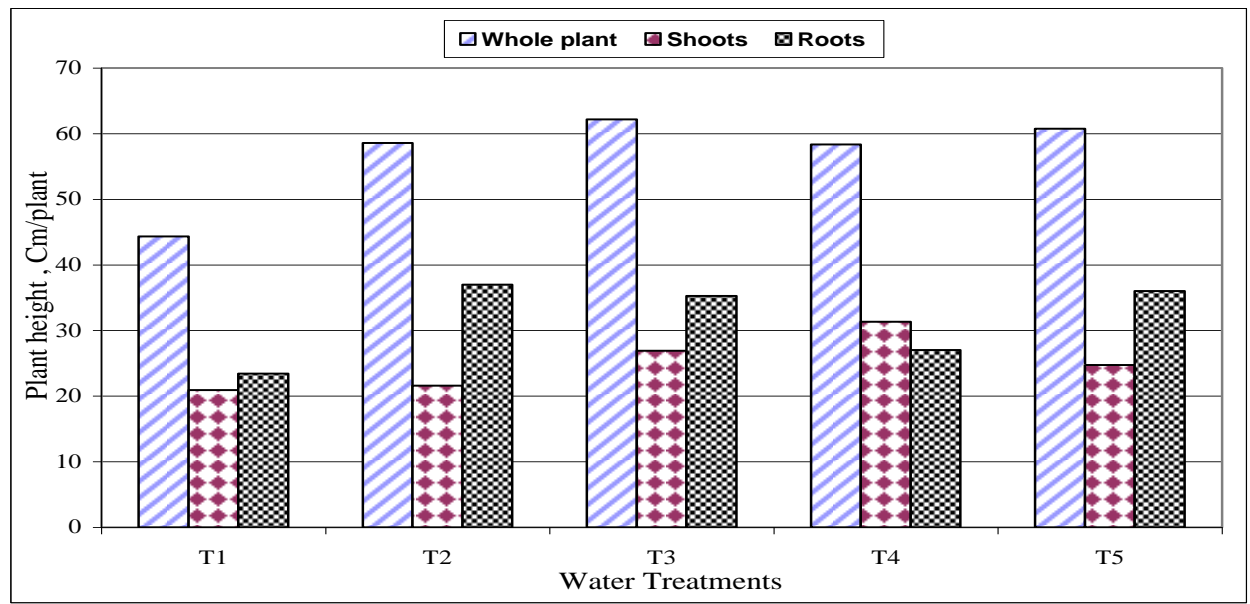

Figure 4: Effect of irrigation water treatments on plant height (cm.plant $\left.{ }^{-1}\right)$ of Lettuce plant

\section{Lettuce leaves number}

Lettuce leaves number as affected by different water quality is presented in Table (3), and graphically illustrated by Fig. (5). It is obvious that treatment of $100 \%$ fresh water (T5) induced the highest value of leaves number followed by treatment of $25 \%$ drainage water mixed with $75 \%$ fresh water (T4), then the treatment of $50 \%$ drainage water mixed with $50 \%$ fresh water (T3).

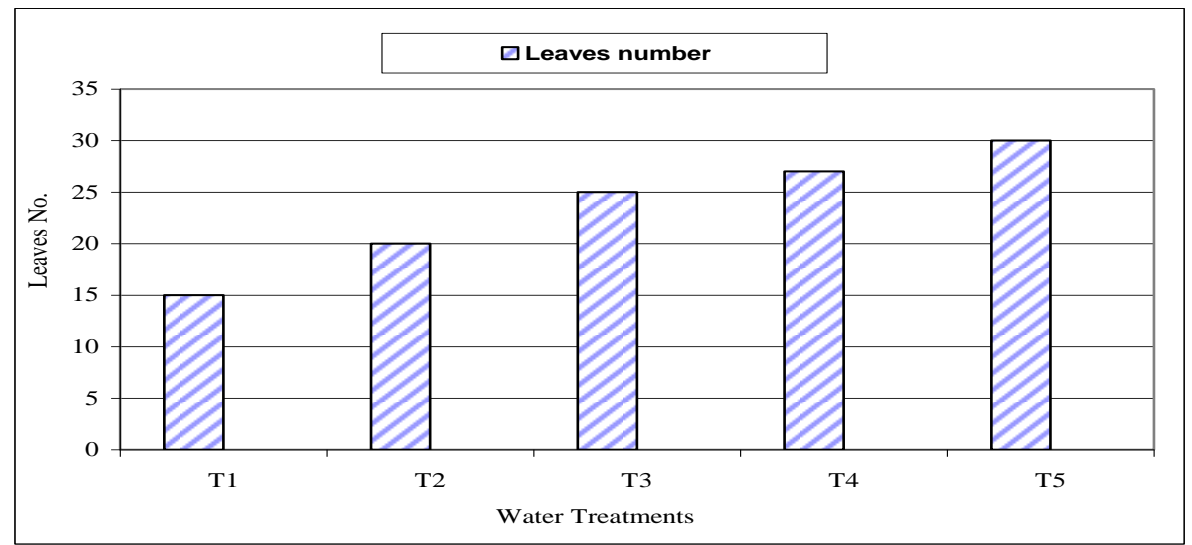

Figure 5: Effect of irrigation water treatments on Leaves Number of Lettuce plants

On the other hand, the treatment of $100 \%$ drainage water (T1) resulted in the lowest value of leaves number followed by T2 (75\% drainage water 
mixed with $25 \%$ fresh water). On the base of fully drainage water treatment, other water quality treatments reflected simple relative increase in leaves number by about $17.5 \%, 47 \%, 59 \%$ and $76 \%$ over $\mathrm{T} 1$ for T2, T3, $\mathrm{T} 4$ and T5, respectively similar results was reported by Ünlükara et al. (2008).

\section{Water use efficiency}

Hydroponically produced lettuce was found to enhance the efficiency of water use (WUE). Bradley and Marulanda (2000) reported that hydroponic green fodder production technique requires only about 10$20 \%$ of the water needed to produce the same amount of crop in soil culture. While Al-Karaki (2010) reported that only 3-5\% of water is needed to produce the same amount of fodder in comparison to that produced under field conditions. Producing Lettuce under hydroponic conditions is a highly efficient process in term of water saving when compared to field production of different plants like lettuce. In this study, the results in table 4 and fig. 6 showed that the highest value of (WUE) was obtained with T3 and the lowest value obtained with T1 as the high fresh yield with T3 and low fresh yield with T1. Irrigation with T3 was found to use water more efficiently in producing Lettuce plant than irrigation with the other water treatments, when used only $1 \mathrm{~m}^{3}$ water to produce $16.67 \mathrm{~kg}$ of hydroponic lettuce in comparison to 29.68 , $39.96,27.88$ and $28.78 \mathrm{~kg}$ of produced lettuce in T1, T2, T3, T4, and T5, respectively.

Table 4: Total water consumption during lettuce cultural cycle and water use efficiency

\begin{tabular}{|c|c|c|c|c|}
\hline \multirow{2}{*}{ Water } & $\begin{array}{c}\text { Total water } \\
\text { consumption }\end{array}$ & $\begin{array}{c}\text { Fresh } \\
\text { matter } \\
\mathrm{kg} / \mathrm{m}^{2}\end{array}$ & $\begin{array}{c}\text { Water use } \\
\mathrm{m}^{3} / \mathrm{kg} \text { fresh } \\
\text { matter }\end{array}$ & $\begin{array}{c}\text { Water use } \\
\text { efficiency } \mathrm{kg} \\
\text { fresh matter/ } \mathrm{m}^{3}\end{array}$ \\
\cline { 2 - 3 } $\mathrm{T} 1$ & 0.24 & 4.00 & 0.060 & 16.67 \\
\hline $\mathrm{T} 2$ & 0.25 & 7.42 & 0.034 & 29.68 \\
\hline $\mathrm{T} 3$ & 0.25 & 9.99 & 0.025 & 39.96 \\
\hline $\mathrm{T} 4$ & 0.26 & 7.25 & 0.036 & 27.88 \\
\hline $\mathrm{T} 5$ & 0.27 & 7.77 & 0.035 & 28.78 \\
\hline
\end{tabular}


Generally, most hydroponic systems will utilize water more efficiently than conventional farming. The volume of water consumed per plant in a hydroponic system is not different from that grown using conventional methods; however, the hydroponic system delivers the water more efficiently, with a larger percentage of the water going to plant evapotranspiration (Sanchez 2014).

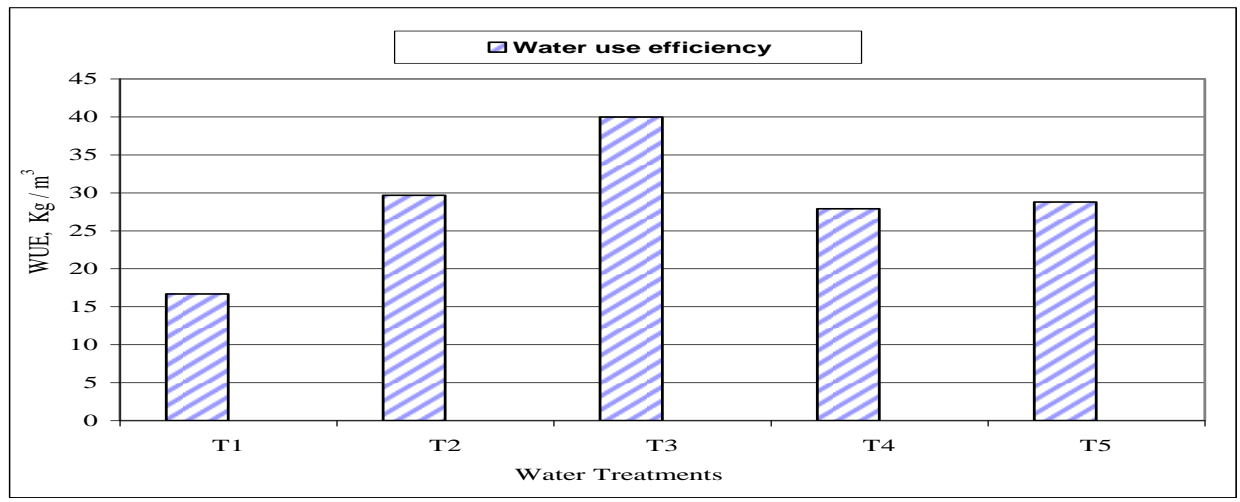

Figure 6: Water use efficiency $\left(\mathrm{kg}^{3}\right)$ for lettuce plant during cultural cycle

This is a tremendous improvement in WUE and indicated that hydroponic system could play a significant role in improving water use efficiency in Egypt and other countries in the region with shortage in irrigation water.

\section{Lettuce quality}

\section{Nutrient minerals contents in Lettuce}

Minerals have a major nutritional significance for human beings and feed deficiencies in elements, such as $\mathrm{N}, \mathrm{P}, \mathrm{K}, \mathrm{Ca}, \mathrm{Cu}, \mathrm{Fe}, \mathrm{Zn}$ and $\mathrm{Mn}$ can lead to a variety of health problems (Liu et al., 2007). Concentration of nutrient elements analyzed in dry Lettuce is presented in Table 5. There were obvious differences in concentrations of the analyzed elements $(\mathrm{N}, \mathrm{P}$, $\mathrm{K}, \mathrm{Ca}, \mathrm{Cu}, \mathrm{Fe}, \mathrm{Zn}$ and $\mathrm{Mn}$ ) between those irrigated with $\mathrm{ADW}$ and with fresh water or ADW mix. The short growing period of Lettuce under hydroponic dependency on its own reserved compounds for the early growing stages may be attributed to the high variations of mineral nutrients in the produced Lettuce irrigated with ADW and fresh water. 
The nutrient requirements of the seedlings after germination are quite low and partially satisfied from the reserved compounds in the seeds (Bewley, 1997).

Table 5. The uptake of mineral nutrients in Lettuce plant produced under hydroponic conditions and irrigated with different water treatments (dry matter basis).

\begin{tabular}{|c|c|c|c|c|c|c|c|c|}
\hline \multirow{2}{*}{$\begin{array}{l}\text { Water } \\
\text { treatment }\end{array}$} & $\mathbf{N}$ & $\mathbf{P}$ & $\mathbf{K}$ & $\mathrm{Ca}$ & $\mathbf{C u}$ & $\mathrm{Fe}$ & $\mathbf{Z n}$ & Mn \\
\hline & \multicolumn{4}{|c|}{$\mathrm{mg}_{\text {plant }}{ }^{-1}$} & \multicolumn{4}{|c|}{$\mu \mathrm{g}$ plant $^{-1}$} \\
\hline $\mathbf{T 1}$ & 94.25 & 11.25 & 144.64 & 30.56 & 0.27 & 24.99 & 1.457 & 1.278 \\
\hline $\mathbf{T} 2$ & 156.26 & 16.18 & 241.72 & 42.43 & 0.47 & 31.63 & 1.708 & 1.618 \\
\hline T3 & 281.42 & 31.91 & 507.99 & 80.77 & 0.87 & 56.223 & 3.338 & 2.097 \\
\hline $\mathbf{T 4}$ & 347.96 & 29.80 & 568.13 & 117.70 & 1.19 & 46.38 & 2.807 & 1.809 \\
\hline T5 & 479.07 & 34.53 & 636.45 & 172.58 & 1.11 & 37.42 & 2.746 & 1.378 \\
\hline
\end{tabular}

The high concentrations of macro nutrients $\mathrm{N}, \mathrm{P}, \mathrm{K}$ and $\mathrm{Ca}$ in dry Lettuce irrigated with T5 might be due to their high concentrations in the nutrient solution used for irrigation. This might indicate that the nutrient solution concentrations affected on nutrient uptake by lettuce plant. Samarakoon et al., 2006 showed that increasing nutrient concentration above EC level 2 $\mathrm{dS} / \mathrm{m}$ increased nutrients $(\mathrm{N}, \mathrm{P}, \mathrm{K}, \mathrm{Ca})$ uptake by lettuce plant. On the other hand, all micro nutrient except for $\mathrm{Cu}$, were high in plants irrigated with $\mathrm{T} 3$ may be due to high dry weight value with T3. Generally, the results of this study indicated that the contents of those essential minerals were available in the produced Lettuce around their usual level, thus, ADW can be used for irrigation when mixed with fresh water in ratio of $(50 \%$ : $50 \%$ ), (T3) under hydroponic conditions without any adverse effects regarding to these conditions and elements.

\section{Heavy metals contents in lettuce plant}

Application of ADW in irrigation crops usually contain elevated levels of heavy metals (specifically $\mathrm{Cd}, \mathrm{Ni}, \mathrm{Cr}$ and $\mathrm{Pb}$ ) which might accumulate in Plants and cause toxic effects on human (Adriano et al., 2005). In this study, Heavy metals $(\mathrm{Cd}, \mathrm{Ni}, \mathrm{Cr}$ and $\mathrm{Pb})$ concentrations in Lettuce were higher in T3 than different water treatments irrigated plants (Table 6). May be due to dry weight effect but these are below the limits set by WHO and FAO for leafy vegetables and fresh herbs (WHO/FAO, 2007). 
Table 6. The concentration of heavy metals $\left(\mu \mathrm{g} \mathrm{plant}^{-1}\right)$ in Lettuce plant produced under hydroponic conditions and irrigated with different water treatments.

\begin{tabular}{|c|c|c|c|c|}
\hline \multirow{2}{*}{ Water Treatment } & $\mathrm{Cd}$ & $\mathrm{Ni}$ & $\mathrm{Cr}$ & $\mathrm{Pb}$ \\
\cline { 2 - 5 } & \multicolumn{4}{|c|}{$\mathrm{gg} \mathrm{plant}^{-1}$} \\
\hline $\mathrm{T} 1$ & 0.14908 & 0.572 & 0.806 & 0.12399 \\
\hline $\mathrm{T} 2$ & 0.14514 & 0.790 & 1.153 & 0.13164 \\
\hline $\mathrm{T} 3$ & 0.16615 & 1.212 & 2.136 & 0.14821 \\
\hline $\mathrm{T} 4$ & 0.10599 & 1.111 & 1.639 & 0.13393 \\
\hline $\mathrm{T} 5$ & 0.09189 & 1.114 & 1.407 & 0.10373 \\
\hline Mean & 0.13165 & 0.960 & 1.428 & 0.12830 \\
\hline $\begin{array}{c}\text { Safe limits in plants } \\
\text { (vegetative parts) } \\
\text { (mg/l) }\end{array}$ & $0.2^{\dagger}$ & $1.5^{\dagger}$ & $20^{\ddagger}$ & $5.0^{\dagger}$ \\
\cline { 2 - 5 } & \multicolumn{4}{|c}{} \\
\hline
\end{tabular}

$\uparrow$ according to WHO/FAO (2007)

\section{CONCLUSIONS}

Nutrient Film Technique (NFT) Hydroponic system is a potential technique for Lettuce production with less water consumption where water is the main limiting factor for agricultural production. Agricultural drainage water (ADW) is a feasible source for irrigation of hydroponically produced Lettuce. The current study shows the superiority of (T3) ADW mixed with fresh water in ratio 0.5/0.5 irrigated Lettuce over that irrigated with other water treatments in several aspects related to production and quality of the produced Lettuce crop. This indicated that ADW is a good source of nutrients needed for plant growth to promote high yields when mixed with fresh water T3. The accumulation of heavy metals in the Lettuce plants irrigated with ADW was apparent, yet below FAO accepted limits. The use of ADW in hydroponic systems may reduce the risk of heavy metal accumulation in the soil with prolonged use. It is also considered an environmentally sound ADW disposal practice compared to direct disposal into surface or ground water bodies. Moreover, plants irrigated with T3 used water more efficiently than those irrigated with other water treatments, Water Use Efficiency (WUE) were 16.67, 29.68, 39.96, 27.88 and $28.78 \mathrm{~kg} / \mathrm{m}^{3}$ for T1, T2, T3, T4, and T5, respectively. The results of this work revealed that Lettuce could be irrigated safely with agricultural drainage water (ADW) mixed with fresh 
water in ratio of $(50 \%: 50 \%)(\mathrm{T} 3)$ to produce high yield and less water use. Moreover, use of agricultural drainage water (ADW) in irrigation of Lettuce in hydroponic system considered as useful alternative disposal method of wastewater without the risk of accumulation of heavy metals in the soil.

\section{REFERENCES}

Abdel-Lateef, E.M., Hall, J.E., Farrag, M.A.A., Farrag, A.A. 2011. Agro-Economic Studies on Wastewater Reuse in Developing Marginal Areas in West Delta, Egypt. International Journal of Water Resources and Arid Environments 1(2), 110-115.

Albright, L.D.; Langhans, R.W. 2014. Controlled Environmental Agriculture Scoping Study. Controlled Environment Agriculture Program, Cornell University. Available online: http://www.cornellcea.com/attachments/Controlled\%20Environmen t\%20Agriculture $\% 20$ Scoping $\% 20$ Study $\% 20$ pdf $\% 20 \% 20$ Adobe $\% 20$ Acrobat\%20Professional.pdf (accessed on 11 November 2014).

Al-Karaki, G. N. 2010. Hydroponic green fodder: alternative method for saving water in dry areas. Proceedings of the "Second Agricultural Meeting on Sustainable Improvement of Agricultural and Animal Production and Saving Water Use. September 2010, Sultanate of Oman.

Al-Maskri, A., L. Al-Kharusi and H. Al-Miqbali, 2010. Effects of salinity stress on growth of lettuce (Lactuca sativa) under closedrecycle nutrient film technique. Int. J. Agric. Biol., 12: 377-380.

Andriolo, J.L., G.L. Da Luz, M.H. Witter, R.S. Godoi, G.T. Barros and O.C.Bortolotto, 2005. Growth and yield of lettuce plants under salinity.Hort. Brazil., 23: 931-934.

Awady, M.N.; G.W. Amerhom and S.M. Zaki, 1976. Trickle irrigation trial on pea in conditions of Qalubia Egypt J. Hort. 3, No. 1, pp. 99110 .

Benton, J. 2005. Hydroponics; A practical Guide for the Soilless Grower. $2^{\text {nd }}$ Ed. CRC press, USA.

Bewley, J. D. 1997. Seed germination and dormancy. The Plant Cell. 9:1055-1066. 
Bos, M.G. 1980. Irrigation efficiency at crop production level. ICID Bulletin, 29(2):18-26. ICID, New Delhi, July 1980 (also in French and Spanish).

Bradley, P. and C. Marulanda. 2000. Simplified Hydroponics to Reduce Global Hunger. Acta Hort. 554:289-295.

Brechner, M.; Both, A.J. 2014. "Hydroponic Lettuce Handbook". Cornell Controlled Environment Agriculture. Cornell University. Available online: http://www.cornellcea.com/attachments/ Cornell CEA Lettuce Handbook.pdf (accessed on 2 December 2014).

FAO (Food and Agriculture Organization of the United Nations). 1992. Wastewater quality guidelines for agricultural use. In: Pescod, M.B. (Ed) Wastewater treatment, and use in agriculture FAO irrigation and drainage paper 47. Rome, Italy. pp 25-35.

Genuncio, G.C., M. Gomes, A.C. Ferrari, N. Majerowicz and E. Zonta (2012). Hydroponic lettuce production in different 21 concentrations and flow rates of nutrient solution. Horticultura Brasileira 30: 526-530.

Gonnella M., F. Serio G. Conversa and P. Santamaria 2003. Yield and Quality of Lettuce Grown in Floating System Using Different Sowing Density and Plant Spatial Arrangements. Proc. 6th IS on Protected Cult. Eds: G. La Malfa et al.Acta Hort 614, ISHS. Hunger. Acta Hort. 554:289-295.

Keller R., K. Perim, S. Semionato, E. Zandonade, S. Cassini, and R.F. Gonçalves, 2005. Hydroponic cultivation of lettuce (Lactuca sativa) using effluents from primary, secondary and tertiary + UV treatments .Water Science and Technology: Water Supply Vol 5 No 1 pp 95-100.

Khater, E. G. (2006). Aquaponics: the integration of fish and vegetable culture in recirculating systems. M. Sc. Thesis, in Agric. Eng., Fac. Agric., Moshtohor, Benha Univ., Egypt.

Liu, K., K. L. Peterson and V. Raboy. 2007. Comparison of the phosphorus and mineral concentrations in bran and abraded kernel fractions of a normal barley (Hordeum vulgare) cultivar versus four low phytic acid isolines. J. Agric. Food Chem. 55:4453-4460. 
Rababah, A. A. and N. J. Ashbolt. 2000. Innovative production treatment hydroponic farm for primary municipal sewage utilization. Water Res. 34(3):825-834.

Rababah, A. and A. Al-Shuha. 2009. Hydroponics reducing effluents heavy metals discharge. Water Sci. Tech. 59:175-183.

Ryan, J., G. Estefan, and A. Rashid. 2001. Soil and Plant Analysis Laboratory Manual. 2ed. International Center for Agricultural Research in the Dry Areas ICARDA, Aleppo, Syria.

Samarakoon U.C., Weerasinghe P.A., and Weerakkody W.A.P., 2006. Effect of Electrecal Conductivity[EC] of the nutrient solution on nutrient uptake,Growth and yield of leaf lettuce(Lactuca sativa L.)in stationary Culture. Tropical Agricultural Research vol. 18.

Sanchez, S.V. (2014).Avaliação de alface crespa produzidas em hidropônia tipo NFT em dois ambientes protegidos em Ribeirão Preto (SP). Paulista State University, College of Agricultural and Veterinary Science.

Schouwenberg, V., J. C. Walinge. 1973. Methods of analysis for plant material. Agric. Univ. Wageningen, The Netherlands.

Sezen, S.M, G. Celikel, A. Yazar, S. Tekin and B. Kapur. 2010. Effect of irrigation management on yield and quality of tomatoes grown in different soilless media in a glasshouse. Sci. Res. Essays 5(1):41-48.

Snow, A. M. and A. E. Ghaly. 2008. Use of Barley for the Purification of Aquaculture Wastewater in a Hydroponics System. Amer. J. Environ. Sci. 4(2):89-102.

Tognoni, F.; Pardossi, A. 2015. Chapter 15: Soil-less Culture for Greenhouse Crops in the Mediterranean Countries. Methyl Bromide Alternatives for North African and Southern European Countries. United Nations Publication. ISBN: 92-807-1803-3. Available online:http://www.unep.fr/ozonaction/information/mmcfiles/3204e.pdf (accessed on 30 January 2015).

Ünlükara, A., B. Cemek, S. Karaman and S. Erşahin, 2008. Response of lettuce (Lactuca sativa var. crispa) to salinity of irrigation water. New Zealand J. Crop Hort. Sci., 36: 265-273.

Vaillant N, F. Monnet, H. Sallanon, A. Coudret, and A. Hitmi. 2004. Use of commercial plant species in a hydroponic system to treat domestic wastewaters. J. Environ. Qual. 33(2):695-702. 
Vernieri, P., Borghesi, E., Ferrante, A., Magnani, G., 2005. J. Food Agric. Environ. 34,86-88.

Watanabe, F. S. and S. Olsen. 1965. Test of an ascorbic acid method for determining phosphorus in water and $\mathrm{NaHCO} 3$ extract for soil. Soil Sci 21:677-678.

WHO/FAO. 2007. Joint FAO/WHO Food Standard Programme Codex Alimentarius Commission 13th Session. Report of the Thirty Eight Session of the Codex Committee on Food Hygiene. Houston, United States of America.

Yang, Z. S. Zheng, J. Chena and M. Suna. 2008. Purification of nitraterich agricultural runoff by a hydroponic system. Biores. Techn. 99:8049-8053.

$$
\begin{aligned}
& \text { الملخص العربى } \\
& \text { استخدام مياه الصرف الزراعي لإنتاج الخس في نظام الزراعة المائية } \\
& \text { عبد التواب متولي إبراهيم زيدان }
\end{aligned}
$$

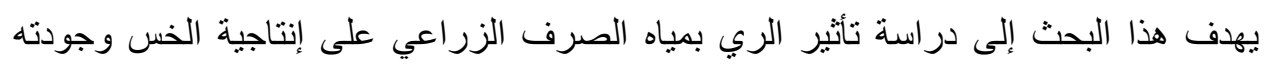

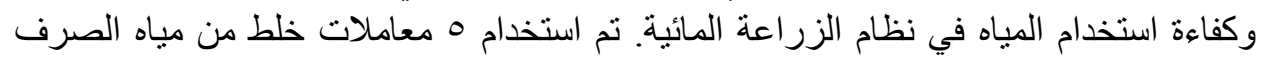

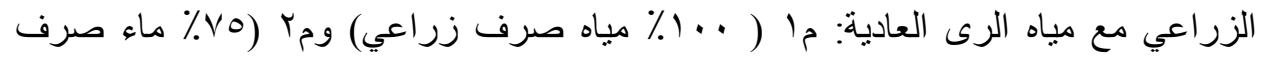

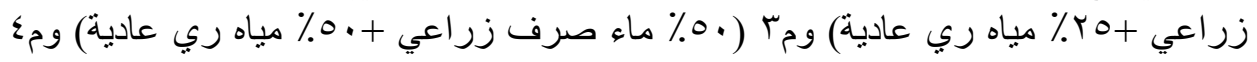

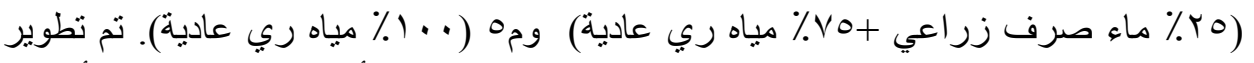

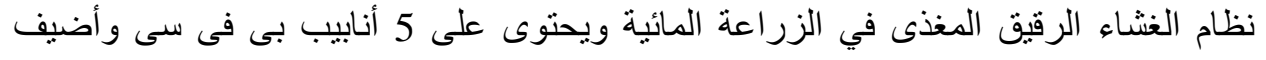

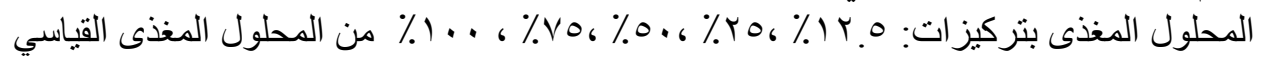

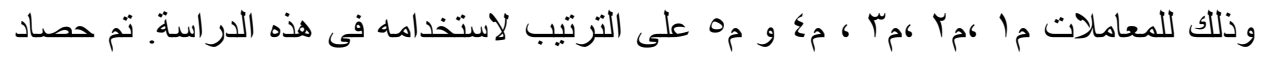

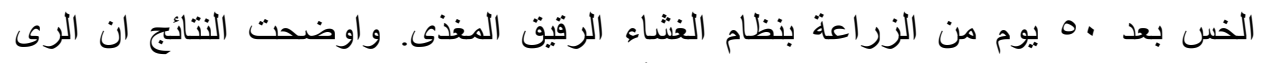

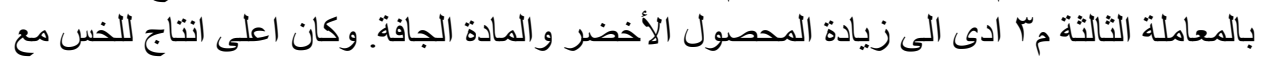

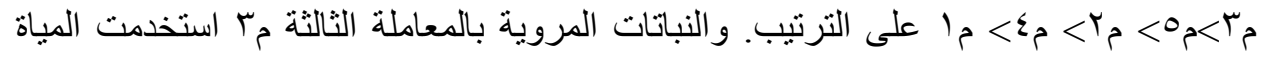

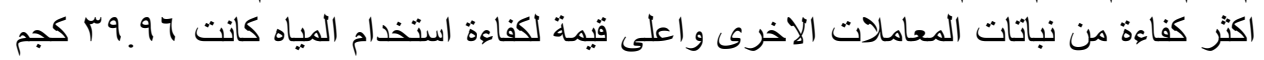

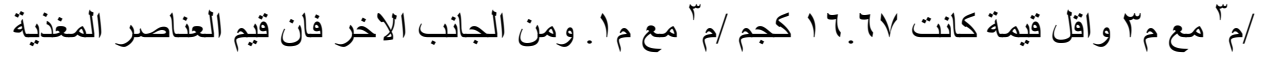

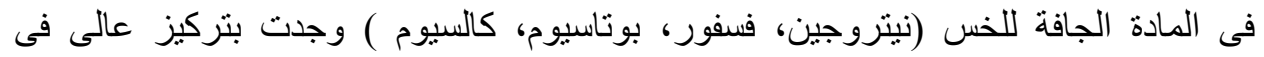

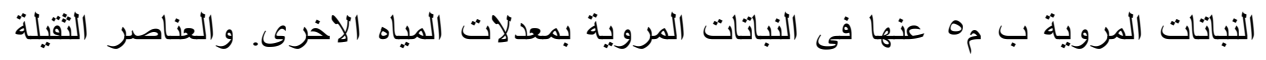

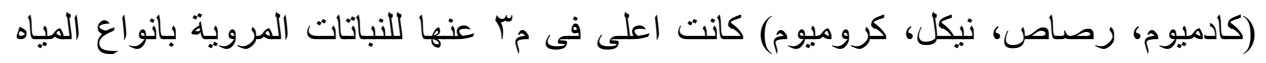

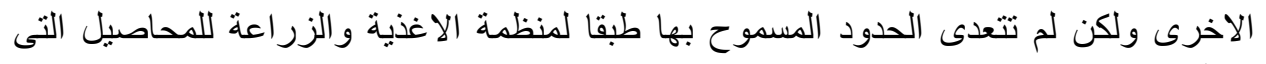

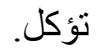

